\title{
On the Current Situation and Prospect of New Media Art Curriculum in China's Colleges and Universities
}

\author{
Xinquan Wang \\ Arts and Media College of Bohai University, Jinzhou Liaoning, 121000, China
}

Keywords: colleges and universities; new media art; current situation; curriculum

\begin{abstract}
With the rapid development of China's economy and science and technology, the times have put forward new requirements for education in China. It is necessary for education organizers in Chinese colleges and universities to think about how to adapt to the development of the information and digital era, and use high-tech means to assist the progress of China's education and teaching. In order to satisfy the requirements of the society to art education in colleges and universities, new media art curriculum in Chinese colleges and universities has been established and develops continuously. Many colleges and universities realize the significance of new media art curriculum and major, determine the development of art curriculum with new media as methods, consider new media art as an important subject, and cultivate more talents with the proficiency. This paper analyzes and discusses the current situation of new media art curriculum in China, finds out problems and corresponding measures in the development of new media art curriculum, and has prospect and thinking on the future of new media art curriculum in colleges and universities.
\end{abstract}

Today, in the 21st century, we have already lived in the digital age. All new media have become special carriers of new media art. As a foreign product, new media art "imported" has developed in China for more than 20 years, we gradually moved from the simple imitation to the independent innovation, and new media art curriculum has also been widely popularized in colleges and universities. However, problems also appear with satisfying effects obtained. It is necessary for us to explore how to develop new media art in college and universities for more progress.

\section{The background of problems}

With the economic development and scientific and technological progress in China, we are now in the digital and information era, new media art has already enter the work, study and life. The production of film and television works, animation production, commercial advertising, computer games, music video, industrial design, etc., all urgently require the technology of China's new media art as a support ${ }^{[1]}$. Under the strong demand of social life and commercial market, the new media art curriculum in Chinese colleges and universities has emerged, and in fine art colleges and other art colleges of other comprehensive universities. Colleges and universities that already had the course start to increase their investment in various resources and equipment, increase their emphasis, and gradually increase the number of students enrolled in this course. However, in the process of rapid development and progress of new media art curriculum in China, problems gradually emerge, especially compared to other mature professional courses in colleges and universities, the education and teaching of this course is still not perfect enough. Therefore, it is necessary to speed up the adjustment of new media art curriculum in colleges and universities, optimize all aspects, and promote its healthy growth and development.

\section{The current situation of new media curriculum in colleges and universities in China}

The education of new media art professional course in most fine art colleges and universities in China, on the whole, is weak, mainly because the course is still in growth and the overall development is not perfect enough. Moreover, as for the social and technological environment, the digital industry in China starts relatively late. Although satisfying results have been obtained in 
technological development in recent years, it is mainly concentrated on certain high-tech Internet companies. In the development of new media courses in colleges and universities in China, the faculty is weak, accompanied by the relatively backward teaching hardware environment and the relative backwardness of the concept of new media art development.

\section{Problems in new media art curriculum in colleges and universities}

\subsection{Lack of focus in the subject}

The establishment of the subject should be clear. The field of new media art is very extensive, and we cannot think about this problem in an abstract way. Is this professional course of new media art the whole content of new media art in advanced society? The answer is obviously no. The content of new media art mainly include mainstream media related technologies, digital image processing, animation production principle, digital photography and video, related production design of online games, application of multimedia digital technology, video special effects and non-linear editing technologies and etc. ${ }^{[3]}$ The content of each technology is very complex and diverse, and it takes a long time from initial learning to proficiency. Therefore, for the knowledge content contained in the new media art, we cannot learn everything, and it is even more impossible to achieve mastery of all of them in a limited number of years of study in colleges and universities. The results are impossible from both the theoretical and practical perspective. Therefore, the content of the teaching shall be subdivided in the new media art courses in colleges and universities with different focuses. It is necessary for us to scientifically formulate the courses according to the current professional characteristics, subject advantages, and teaching resources of the university, and create a focused technical course in the new media art majors based on personal interests and personal expertise of students.

\subsection{Lack of emphasis on the cultivation of students' competence in the teaching.}

From the current situation of new media art curriculum in colleges and universities, apparently, the cultivation of students' competence is not emphasized in the teaching. In the teaching, we should take the grasp and application of technological ability of new media art curriculum into account, and cultivate the development and innovation capabilities of students in new media art. It is necessary to fully consider the students' actual understanding and mastery of the course, combine the characteristics and efficiency of the students' learning, and add some content that can cultivate the students' learning and operation skills in the teaching process, so that students can not only study this course, but grasp this course, and has a certain degree of practical ability after graduation, rather than just knowledge theory, but a completely new in practice.

\subsection{The weak quality of the faculty in the curriculum.}

According to actual national conditions in China, new media art is a new and emerging major, and most of the teachers in current new media art course also started halfway. They do not have enough grasp and understanding of this course in the beginning, which results in the fact that the quality of the faculty of this course in colleges and universities in China is not so high. In this case, it is difficult to accomplish the tasks of teaching or achieve a certain teaching effect. Therefore, from the perspective of the faculty, the development of new media art courses in colleges and universities in China is still worrying. For teachers of this course in some colleges and universities, the overall quality and teaching ability are low, and cannot meet the teaching requirements of the new media art professional courses, which is a very serious impact. Therefore, it is necessary for us to focus on improving the teaching staff of new media courses and improve the comprehensive ability of the teaching staff. 


\section{Measure of problems in new media art curriculum in colleges and universities.}

\subsection{To determine the focus of the teaching of new media art curriculum.}

The new media art courses in colleges and universities with different teaching background and teaching conditions should be different, and with different platforms and conditions to support the curriculum. Colleges and universities should scientifically set focus, teaching knowledge and orientation of new media art professional courses based on actual situation, teaching background, teaching conditions and teaching characteristics. At the same time, according to the teaching conditions and equipment provided, the content of the course will be selected, scientifically and reasonably matched with all existing teaching conditions, and the advantages of digital media teaching will be fully displayed.

\subsection{To adjust cultivation objectives oriented by the market.}

The teaching task of colleges and universities is not only to train professional talents, but professional talents to serve the society. Therefore, it is necessary to combine the teaching of the course in colleges and universities with real requirements of the market, formulate teaching orientation and content based on the real demand for talents of the social market, and cultivate applied professional talents who can directly adapt to the workplace after graduation. We should develop special training for students in the new media art curriculum, combining the technologies and content that the market really needs, such as joint teaching practice with some local new media companies to determine the practical knowledge and skills that students have ${ }^{[6]}$. Professional new media art talents who can serve the needs of the market, solve the employment problems of the market and serve the enterprise shall be cultivated oriented by the market.

\subsection{To improve the quality of the faculty and increase investment in teaching.}

It is already mentioned that for the current education and teaching of new media art courses in our country, the strength of teachers in our colleges and universities is always not strong enough, which has become the main reason restricting the development of new media professional courses in our country. At the same time, colleges and universities should also increase the investment in new media arts courses, from manpower, material resources, to financial resources, and try to meet the conditions required by the new media curriculum majors so as to promote the rapid and healthy development of new media art curriculum in colleges and universities in our country.

\subsection{To enrich teaching content of the curriculum.}

The science and technology in China is continuously developing, correspondingly, technologies and content of new media art shall be incessantly optimized. Therefore, new media art course in colleges and universities shall be adjusted correspondingly, curriculum content enriched with the times to be close to international standards and innovations and reform in international new media art focused all the time so as to learn and introduce advanced content and knowledge of new media art at abroad to keep pace with digital media trend in the world.

\section{Prospect on new media art curriculum in China in the future.}

In the future, new media curriculum in colleges and universities in China can develop more scientifically. It can be predicted that the teaching of new media art courses in China will be gradually optimized. The art in the new media art curriculum should be valued, and the curriculum will shift to be art-oriented with technical skills, and the teaching content of digital technology will be infiltrated to create and inspire the development of students' artistic imagination. At the same time, it is important for us to attach importance to traditional art, be bold in inheritance and innovation, draw the best, remove the worst, take the excellence, and focus on promoting traditional Chinese culture, achieve close integration between theory and practice, and pay attention to the cultivation of students' abilities. Colleges and universities can transform education concept, deepen 
teaching reform, and attach importance to practicality and innovation to master the latest knowledge and technology; the international cooperation and communication in new media art shall be emphasized for us to widen the horizon, seize more opportunities, and offer a better platform for the construction of new media curriculum; in the future, more advanced educational technology and equipment will be incessantly introduced in the teaching to provide better curriculum experience of new media art courses and realize the better development of new media art curriculum education in China.

\section{Conclusion}

It is inevitable that new media art will be the mainstream of art in the future with better development prospect. Besides, colleges and universities in China is now providing professional new media talent into the new media industry. Therefore, it is necessary for colleges and universities to focus on the construction of teaching staff in new media art curriculum, improve the comprehensive teaching competence and teaching level of teachers, increase investment in all teaching equipment, provide abundant material conditions for new media art curriculum and select teaching content according to teaching conditions and equipment provided. Meanwhile, there should be a focus on specific course content of the teaching, content shall be enriched to innovate with the times, and the content of new media art courses shall be adjusted from the requirements of the market so as to transport professional talents to the society to promote the overall development of new media art industry in China.

\section{References}

[1] Xu Yunchun. The New Movement of Visual Art Education: The Research of New Media Art Curriculum and Teaching in Secondary School in the Background of Digital Age. [D]. East China Normal University, 2015.

[2] Lu Fang. China's New Media Art Education Development Research [D]. Harbin Normal University, 2012.

[3] Li Pengjie. Digital Media Art College Status and Teaching System. [D]. Hebei Normal University, 2010.

[4] Huang Long. On Characteristics and Teaching of New Media Art in Colleges and Universities [J]. Forum on Contemporary Education (The 2nd Issue of the Month), 2009(05):121-122.

[5] Deng Hui. The Research of New Media Art Education [D]. Hunan Normal University, 2007.

[6] Liao Ye. The Present Condition and Consideration about the "New Media Art" [J]. Journal of Hengyang Normal University, 2006(01):174-176. 